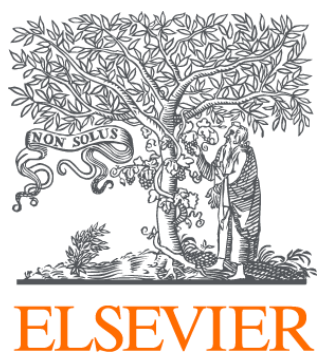

Since January 2020 Elsevier has created a COVID-19 resource centre with free information in English and Mandarin on the novel coronavirus COVID-

19. The COVID-19 resource centre is hosted on Elsevier Connect, the company's public news and information website.

Elsevier hereby grants permission to make all its COVID-19-related research that is available on the COVID-19 resource centre - including this research content - immediately available in PubMed Central and other publicly funded repositories, such as the WHO COVID database with rights for unrestricted research re-use and analyses in any form or by any means with acknowledgement of the original source. These permissions are granted for free by Elsevier for as long as the COVID-19 resource centre remains active. 


\title{
Vitamin D deficiency and the COVID-19 pandemic
}

\author{
Patrick Zemb ${ }^{\mathrm{a}, *}$, Peter Bergman ${ }^{\mathrm{b}}$, Carlos A. Camargo $\mathrm{Jr}^{\mathrm{c}}$, Etienne Cavalier ${ }^{\mathrm{d}}$, \\ Catherine Cormier ${ }^{\mathrm{e}}$, Marie Courbebaisse ${ }^{\mathrm{f}}$, Bruce Hollis ${ }^{\mathrm{g}}$, Fabrice Joulia ${ }^{\mathrm{n}}$, \\ Salvatore Minisola ${ }^{\mathrm{h}}$, Stefan Pilz ${ }^{\mathrm{i}}$, Pawel Pludowski $\mathrm{j}^{\mathrm{j}}$, François Schmitt ${ }^{\mathrm{k}}$, \\ Mihnea Zdrenghea ${ }^{\prime}$, Jean-Claude Souberbielle ${ }^{\mathrm{m}}$ \\ a Gynecology Department, Centre hospitalier de Lorient, Lorient, France \\ ${ }^{\mathrm{b}}$ Department of Laboratory Medicine, Karolinska Institutet, Stockholm, Sweden \\ c Department of Emergency Medicine, Massachusetts General Hospital, Harvard Medical School, Boston, MA, USA \\ ${ }^{\mathrm{d}}$ Department of Clinical Chemistry, University of Liège, CHU de Liège, Liège, Belgium \\ e Department of Rheumatology, Cochin Hospital, AP-HP, Paris, France \\ ${ }^{\mathrm{f}}$ Department of Physiology, Georges Pompidou European Hospital, AP-HP, Paris, France \\ g Medical University of South Carolina, Charleston, SC, USA \\ h Department of Clinical, Internal, Anaesthesiologic and Cardiovascular Sciences, 'Sapienza', Rome University, Viale del Policlinico 155, Rome, 00161 Italy \\ ${ }^{\mathrm{i}}$ Division of Endocrinology and Diabetology, Department of Internal Medicine, Medical University of Graz, Graz, Austria \\ ${ }^{\mathrm{j}}$ Department of Biochemistry, Radioimmunology and Experimental Medicine, The Children's Memorial Health Institute, Warsaw, Poland \\ ${ }^{\mathrm{k}}$ Department of Laboratory Medicine, Centre hospitalier de Lorient, Lorient, France \\ ${ }^{1}$ Iuliu Hatieganu University of Medicine and Pharmacy, Cluj-Napoca, Romania \\ ${ }^{\mathrm{m}}$ Department of Physiology, Necker-Enfants malades hospital, AP-HP, Paris, France \\ ${ }^{n}$ Center of Research in Cardiovascular and Nutrition (C2VN), Aix-Marseille University E INSERM 1260, France
}

\section{A R T I C L E I N F O}

\section{Article history:}

Received 24 April 2020

Received in revised form 5 May 2020

Accepted 19 May 2020

Available online 29 May 2020

\section{Keywords:}

Vitamin D

coronavirus

respiratory infections

Covid-19

The COVID-19 (coronavirus disease 2019) pandemic is having a colossal human, societal and economic cost that is encouraging individuals, physicians, collectives and authorities to re-evaluate the benefit/cost ratio of the various resources that could help us to better address the crisis-and limit the risk of its recurrence. In this context, we cannot ignore evidence in a recent 'individual patient data' meta-analysis that vitamin D supplementation protects against acute respiratory infections (ARIs) [1]. In this meta-analysis of 25 randomised controlled trials (RCTs) for which the full data of almost 11000 individual patients were available, subgroup analyses revealed that the benefit was observed in those who received frequent (e.g. daily) doses of vitamin D but not in those who received bolus doses, and that the effect was largest when

\footnotetext{
* Corresponding author.

E-mail address: patrick.zemb@orange.fr (P. Zemb).
}

vitamin D was given to individuals with vitamin D deficiency. Since then, several new RCTs have been published with mixed results, with some studies showing beneficial effects of vitamin D on ARIs while other did not. It is known that vitamin D stimulates innate immunity and modulates acquired immunity [2], explaining at least in part how vitamin D may fight against ARIs. Given that vitamin D deficiency is very common [3], especially during the 'cold' season owing to a lack of sunlight exposure, and given that containment at home will prevent sunlight exposure for many people worldwide, even in spring/summer, we believe that vitamin D supplementation should be encouraged, at least in any individual with risk factors of vitamin D deficiency (e.g. obesity, old age, dark skin, wearing covering clothes, no sunshine exposure). We acknowledge that while COVID-19, caused by severe acute respiratory syndrome coronavirus 2 (SARS-CoV-2), is a type of ARI, we have no data enabling us to assert that vitamin D supplementation will reduce the incidence of COVID-19 infection. 
However, except for certain rare situations of vitamin D hypersensitivity (e.g. mutation in the CYP24A1 gene or sarcoidosis), daily supplementation with moderate doses of vitamin $D_{3}$ is safe. Specifically, there was no increased occurrence of renal stones in recent mega-trials that tested vitamin $\mathrm{D}_{3}$ doses of $2000 \mathrm{IU} /$ day [4] or $4000 \mathrm{IU} /$ day [5]. In conclusion, despite a lack of direct evidence of an effect of vitamin D status on COVID-19 infection, we believe that vitamin $D$ deficiency is an easily modifiable risk factor of ARIs and should be actively corrected through inexpensive, safe and readily-available vitamin $D$ supplements. Even a small decrease in COVID-19 infections would easily justify this intervention. Nevertheless, we acknowledge that specific high-quality data are needed to demonstrate the efficacy of vitamin D supplementation in the prevention of COVID-19.

\section{Funding}

None.

\section{Competing interests}

None declared.

\section{Ethical approval}

Not required.

\section{References}

[1] Martineau AR, Jolliffe DA, Hooper RL, Greenberg L, Aloia JF, Bergman P, et al Vitamin D supplementation to prevent acute respiratory tract infections: systematic review and meta-analysis of individual participant data. BMJ 2017;356:i6583, doi:http://dx.doi.org/10.1136/bmj.i6583.

[2] Brighenti S, Bergman P, Martineau AR. Vitamin D and tuberculosis: where next? J Intern Med 2018;284:145-62, doi:http://dx.doi.org/10.1111/joim.12777.

[3] Cashman KD, Dowling KG, Škrabáková Z, Gonzalez-Gross M, Valtueña J, De Henauw S, et al. Vitamin D deficiency in Europe: pandemic? Am J Clin Nutr 2016;103:1033-44, doi:http://dx.doi.org/10.3945/ajcn.115.120873.

[4] Manson JE, Cook NR, Lee IM, Christen W, Bassuk SS, Mora S, et al. Vitamin D supplements and prevention of cancer and cardiovascular disease. N Engl J Med 2019;380:33-44, doi:http://dx.doi.org/10.1056/NEJMoa1809944.

[5] Pittas AG, Dawson-Hughes B, Sheehan P, Ware JH, Knowler WC, Aroda VR, et al. Vitamin D supplementation and prevention of type 2 diabetes. N Engl J Med 2019;381:520-30, doi:http://dx.doi.org/10.1056/NEJMoa1900906. 